
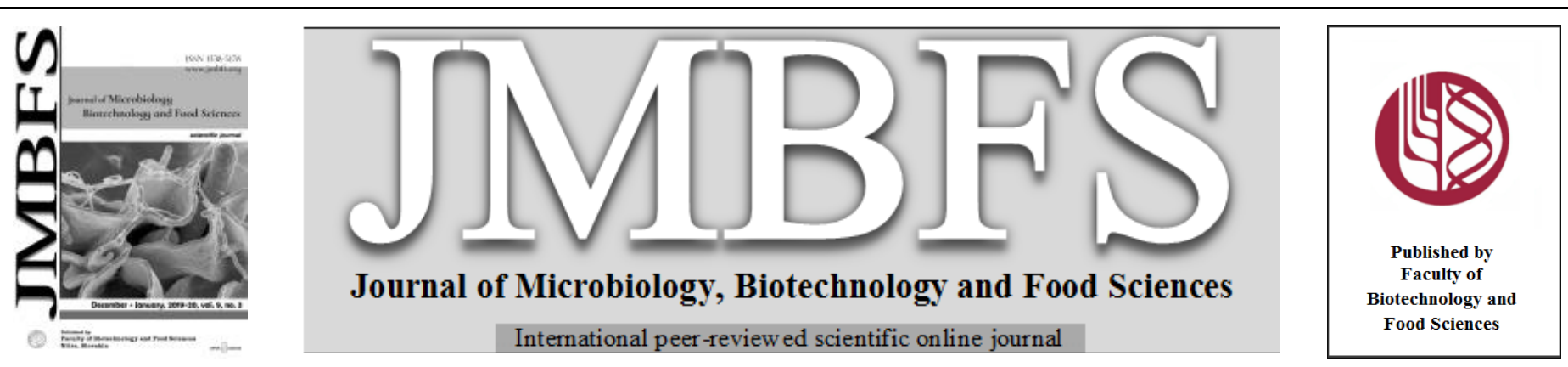

\title{
EVALUATION OF WHITE BREAD PHYSICAL CHARACTERISTICS SUBSTITUTED BY RED KIDNEY BEAN FLOUR WITH DIFFERENT PARTICLE SIZES AND CONCENTRATIONS
}

\author{
Rio Alif Ramzy ${ }^{1}$, Agus Budiawan Naro Putra*l \\ Address(es): Dr. Agus Budiawan Naro Putra, \\ ${ }^{1}$ Indonesia International Institute for Life Sciences, School of Life Sciences, Department of Food Science and Nutrition, Jl. Pulomas Barat Kav. 88, 13210 , Jakarta, Indonesia, (+62)29567899.
}

*Corresponding author: agus.putra@i3l.ac.id

doi: $10.15414 / j m b f s .2019 / 20.9 .3 .610-615$

ARTICLE INFO

Received 3. 4. 2019

Revised 13. 6. 2019

Accepted 13. 6. 2019

Published 1. 12. 2019

Regular article

open $\partial_{\text {Access }}$

\section{ABSTRACT}

The research aimed to study the effect of red kidney bean flour particle size and level of substitution (concentration) on white bread physical characteristics. Red kidney bean-enriched white bread samples, differing in particle sizes (moderately coarse/MC, moderately fine/MF, and standard/ST) and red kidney bean flour concentration (15\% and $20 \%)$, were compared in terms of their physical characteristics, with leavened white bread as control. The bread physical characteristics assessed were oven spring, baking loss, loaf specific volume, mean crumb cell area, crumb cell density, crumb and crust moisture over storage time. It was found that addition of red kidney bean flour, regardless of particle size and concentration, did not have significant effect on oven spring, baking loss, loaf specific volume, and crumb and crust moisture over time. Mean crumb cell area and cell density were significantly improved by red kidney bean flour particle size reduction, not concentration. The result of this research might lay foundation on similar research and provide interesting information which supports the development of healthier bread using red kidney bean flour.

Keywords: red kidney bean flour, particle size, bread physical characteristics

\section{INTRODUCTION}

In light of the growing healthy eating lifestyle, Indonesian consumers start to shift their preference towards healthier food products (EU-Indonesia Business Network, 2016). This trend also applies to white bread, which in the past few years has been increasingly important in Indonesian diet as exemplary by the rise of its expenditure growth $(31.1 \%$ in January 2016$)$ beyond rice $(-4.1 \%$ in January 2016) (Pekerti \& Slette, 2010; Suwanto \& Yapply, 2017). Bread producers should be able to increase the nutritional value of their products to meet the consumer demand.

Pulse has been noted as a very nutritional foodstuff, and is a potential ingredient to improve nutritional value of bread. Nutritionally, pulse in general is source of protein, fibre, potassium and iron, with low glycemic index, sodium and fat content (Food and Agriculture Organization of the United Nations, 2016) Several studies showed that inclusion of pulse flour, such as lentil or jack bean flour, to bread formulation improved bread nutritional value (Rizzello, Calasso, Campanella, De Angelis, \& Gobbetti, 2014; Ugwuona \& Suwaba, 2015). As a commonly found pulse in Indonesia, red kidney bean can be incorporated to enrich white bread due to its high protein $(19.6 \mathrm{~g} / 100 \mathrm{~g}$ bean) and fibre $(24.3$ $\mathrm{g} / 100 \mathrm{~g}$ bean) content as well as low glycemic index ( $31 \pm 5$, white bread standard) (Institute of Nutrition, Mahidol University, 2014; Atkinson, Foster-Powell, \& Brand-Miller, 2008).

In bread quality, apart from nutritional value, bread physical characteristics are also very important because they directly contribute to consumer's perception of bread freshness and eating experience. Good quality bread should have high loaf specific volume (bread volume per gram bread), acceptable oven spring (expansion of bread during baking), soft crumb texture, a crumb structure characterized by small shallow crumb cells with thin cell walls, and slow bread staling (hardening of breadcrumb during storage) (Sahi, Little, \& Ananingsih, 2014). Ingredient interactions during bread making greatly influence bread physical characteristics. Therefore, in the context of improving white bread nutritional value, producers have to pay attention to the bread formulation so that bread physical characteristics are not significantly affected. The consequence is that the utilization of red kidney bean flour to enrich white bread should not considerably change bread physical characteristics.

In the currently available studies, utilization of red kidney bean flour on white bread formulation has yielded bread with improved nutritional values. Red kidney bean flour concentration of $15-20 \%$ were recommended for significantly improving bread nutritional values, yet the resulting bread samples had physical characteristics which signify lower bread quality (Mannonmani, Bhol, \& Bosco, 2014; Bhol \& Bosco, 2014). Mannonmani, Bhol, \& Bosco (2014) found that increasing the flour concentration resulted in reduced loaf specific volume, crumb softness, and overall sensory acceptability. When scanning electron micrograph of the bread was observed, it was found that protein bodies and starch granules from red kidney bean flour disrupted gluten matrix, causing the matrix not to develop properly (Bhol \& Bosco, 2014). Therefore, improving red kidney bean flour-enriched white bread quality remains a challenge, and other ways to improve the bread quality should be explored.

Adjusting red kidney bean flour particle size is a possible way to improve the quality of red kidney bean-enriched white bread. In flour production, particle size adjustment is an important aspect during the milling process due to its effect on flour functionality (Campbell, Webb, Owens, \& Scanlon, 2012). In wheat flour, particle size greatly influences water absorption capacity, which is crucial to gluten network development (Campbell, Webb, Owens, \& Scanlon, 2012; Sivam, Sun-Waterhouse, Quek, \& Ferrera, 2010). Particle size may also significantly influence the functionality of non-wheat flour, such as red kidney bean flour, in bread making (Duodu \& Taylor, 2012). Several studies demonstrated that particle size significantly change functional properties of pulse flour (Borsuk, 2011; Kerr, Ward, McWaters, \& Resurreccion, 2000). However, whether or not the particle size exerts positive effects on bread is greatly influenced by the type of flour (Borsuk, 2011; Borsuk, Arntfeld, Lukow, Swallow, \& Malcolmson, 2012). This research aspired to explore the possibility of adjustment of red kidney bean flour particle size to improve white bread quality. To do this, the research aimed to investigate the effect of red kidney bean flour particle size and level of substitution (concentration) on white bread physical characteristics.

\section{MATERIALS AND METHODS}

\section{Experimental Design}

The research used factorial design, with the factors being red kidney bean flour particle size and level of substitution in bread formulation. Table 1 illustrates the factorial design and the sample group code used in the research. The factor of red kidney bean flour particle size consists of three levels, which are moderately coarse (MC), moderately fine (MF), and standard particle size (ST). Characteristics of MC and MF red kidney bean flour were based on BarbosaCanovás, Ortega-Rivas, Juliano, \& Yan (2006), while ST was based on World 
Health Organization \& Food and Agriculture Organization of the United Nations (2007). The criteria for those particle sizes are described in Table 2. Bread produced from $100 \%$ wheat flour of ST particle size served as control.
Interaction between independent and dependent variables in the research is shown in Table 3.

\begin{tabular}{lcccc}
\multicolumn{2}{l}{ Table 1 Designated code of samples according to level of substitution and flour particle size } & \multicolumn{2}{c}{ Wheat flour particle size } \\
\hline \multirow{2}{*}{$\begin{array}{l}\text { Red kidney bean } \\
\text { level of substitution* }\end{array}$} & \multicolumn{3}{c}{ Red kidney bean flour particle size } & Standard (ST) \\
\hline $0 \%$ & Moderately coarse (MC) & Moderately fine (MF) & Standard (ST) & Control \\
$15 \%$ & MC15 & MF15 & ST15 & \\
$20 \%$ & MC20 & MF15 & ST20 & \\
\hline
\end{tabular}

*Level of substitution refers to the percentage of wheat flour substituted for red kidney bean flour

Table 2 Particle sizes of the types of red kidney bean flour prepared for the research

\begin{tabular}{lllll}
\hline \multirow{2}{*}{ Red kidney bean flour type } & \multicolumn{2}{l}{ Percentage particles which pass the sieve* $(\%)$} & No. $60(\mathbf{0 . 2 5 0} \mathbf{~ m m})$ & No. 70 $(\mathbf{0 . 2 1 0} \mathbf{~ m m})$ \\
\cline { 2 - 5 } & No. $20(\mathbf{0 . 8 4 1} \mathbf{~ m m})$ & No. 40 $(\mathbf{0 . 4 2 0} \mathbf{~ m m})$ & $\leq 40$ & N/A \\
\hline Moderately coarse (MC) & 100 & 100 & 100 & $\leq 40$ \\
Moderately fine (MF) & 100 & 100 & 100 & $\geq 95$ \\
Standard (ST) & 100 & 100 &
\end{tabular}

*The sieve sizes are presented as Tyler Mesh Size (outside brackets) and mm (inside brackets)

Table 3 The interaction between independent and dependent variables in the research

\begin{tabular}{lccc}
\hline \multirow{2}{*}{ Dependent Variable } & \multicolumn{3}{c}{ Independent Variable } \\
\cline { 2 - 4 } & Particle Size & Level of Substitution & Storage Time \\
\hline Fresh crumb moisture & $\mathrm{x}$ & $\mathrm{x}$ & \\
Baking loss & $\mathrm{x}$ & $\mathrm{x}$ & \\
Oven spring & $\mathrm{x}$ & $\mathrm{x}$ & \\
Loaf specific volume & $\mathrm{x}$ & $\mathrm{x}$ & $\mathrm{x}$ \\
Crumb cell density & $\mathrm{x}$ & $\mathrm{x}$ & \\
Mean crumb cell area & $\mathrm{x}$ & $\mathrm{x}$ & $\mathrm{x}$ \\
Crumb moisture over & $\mathrm{x}$ & & $\mathrm{x}$ \\
storage time & & $\mathrm{x}$ & \\
Crust moisture over & $\mathrm{x}$ & & \\
storage time & &
\end{tabular}

$\mathrm{x}$ indicates that the respective independent variable can affect the corresponding dependent variable

\section{Preparation of Red Kidney Bean Flour}

The red kidney bean flour was prepared in different particle sizes. Red kidney bean flour was prepared by grinding raw red kidney bean (Giant Kacang Merah Kering, Mawar Jaya, Jakarta, Indonesia) using coffee grinder, pestle and mortar. The flour was passed through sieves and re-ground until $300 \mathrm{~g}$ of flour with MC, $\mathrm{MF}$, and ST particle size characteristics (refer to Table 2) was produced.

\section{Proximate Analysis of Wheat and Red Kidney Bean Flours}

Moisture analysis was done by oven drying method according to SNI 01-28911992 (National Standardization Agency, of Indonesia, 1992). Ash analysis was done by dry ashing method according to SNI 01-2891-1992 (National Standardization Agency, of Indonesia, 1992). Protein content was determined by Kjeldahl method (National Standardization Agency, of Indonesia, 1992).
Crude fat content was determined by Soxhlet extraction method (National Standardization Agency, of Indonesia, 1992). Crude fibre content was determined according to Association of Official Analytical Chemists (1990). Carbohydrate content was determined by by-difference method (Association of Official Analytical Chemists, 1990). All of the proximate analyses were done in duplicates.

\section{Bread Processing}

The samples were produced according to AACC 10-10B Optimized Straight Dough Method (American Association of Cereal Chemists, 2000) with several modifications. Aside from red kidney bean flour, the ingredients included: highprotein wheat flour (Cakra Kembar, Bogasari Flour Mills, Jakarta, Indonesia), sugar (Giant Gula Pasir Lokal, Giant, Jakarta, Indonesia), instant dry yeast (Fermipan, Lesaffre Yeast Corporation, France), salt (Giant Garam Beryodium, Cheetham Garam Indonesia, Tangerang, Indonesia), shortening (Filma Baker's Cream Fat, Sinarmas Agrobusiness and Food, Jakarta, Indonesia) and diastatic malt powder (Basic Ingredients, Brisbane, Australia). The formulations for the samples are shown in Table 4.

The ingredients were mixed and kneaded for 9 minutes under medium speed (81-85 rpm) in stand mixers (OX-855 Master Standing Mixer, Oxone, Jakarta, Indonesia; KSM150 Artisan Stand Mixer, KitchenAid, Michigan, U.S.A.). As much as $170 \mathrm{~g}$ of the resulting dough was shaped into a ball $(7 \mathrm{~cm}$ diameter $)$ and leavened three times for a total time of 60 minutes at $59 \pm 2 \% \mathrm{RH}$ and $23 \pm 0.5^{\circ} \mathrm{C}$. In-between the proofing, the dough was degassed using pasta roller $(1.25 \mathrm{~mm}$ roll spacing, Vicenza V150AT Pasta Machine, Vicenza, Jakarta, Indonesia) and reshaped. The dough was then taken for final proofing for 24 minutes before baking. The dough was baked in oven (U110 Universal Oven, Memmert, Schwabach, Germany) at $175^{\circ} \mathrm{C}$ for 15 minutes followed by $150^{\circ} \mathrm{C}$ for 20 minutes. A total of three batches were made.

$\underline{\text { Table } 4 \text { Formulation of the bread samples }}$

\begin{tabular}{|c|c|c|c|c|c|c|c|}
\hline \multirow{2}{*}{ Ingredient } & \multicolumn{7}{|c|}{ Weight (g) } \\
\hline & Control & MC15 & MC20 & MF15 & MF20 & ST15 & ST20 \\
\hline High protein white flour & 100 & 85 & 80 & 85 & 80 & 85 & 80 \\
\hline Red kidney bean flour, MC & - & 15 & 20 & - & - & - & - \\
\hline Red kidney bean flour, MF & - & - & - & 15 & 20 & - & - \\
\hline Red kidney bean flour, ST & - & - & - & - & - & 15 & 20 \\
\hline Water & 66 & 66 & 66 & 66 & 66 & 66 & 66 \\
\hline Sugar & 6 & 6 & 6 & 6 & 6 & 6 & 6 \\
\hline Shortening & 3 & 3 & 3 & 3 & 3 & 3 & 3 \\
\hline Instant dry yeast & 8.6 & 8.6 & 8.6 & 8.6 & 8.6 & 8.6 & 8.6 \\
\hline Salt & 2 & 2 & 2 & 2 & 2 & 2 & 2 \\
\hline Diastatic malt powder & 0.2 & 0.2 & 0.2 & 0.2 & 0.2 & 0.2 & 0.2 \\
\hline
\end{tabular}

Legend: MC - moderately coarse particle size; MF - moderately fine particle size; ST - standard particle size. MC15: bread with $15 \%$ white flour substituted for MC red kidney bean flour; MC20: bread with 20\% white flour substituted for MC red kidney bean flour; MF15: bread with 15\% white flour substituted for MF red kidney bean flour; MF20: bread with 20\% white flour substituted for MF red kidney bean flour; ST15: bread with 15\% white flour substituted for ST red kidney bean flour; ST20: bread with $20 \%$ white flour substituted for ST red kidney bean flour

\section{Bread Physical Characteristics Assessment}

\section{Oven Spring}

Oven spring was determined according to Shittu et al. (2008). Dough heights prior to baking and after baking and cooling were measured using digital caliper (Guilin Guanglu Measuring Instruments Co. Ltd., Guilin, China). The oven spring was determined using the following calculation.
Oven spring $(\mathrm{mm})=$ Dough height - bread height

\section{Loaf Specific Volume}

Loaf specific volume was determined by measuring loaf weight, height, and diameter, then approximated using the formula below, assuming a half oblate ellipsoid shape. Loaf specific volume was presented as $\mathrm{cm}^{3} / \mathrm{g}$ loaf. 
Loaf volume $\left(\mathrm{cm}^{3}\right)=\frac{1}{2} \times \frac{4}{3} \times \pi \times(\text { loaf radius })^{2} \times$ loaf height

Loaf specific volume $\left(\mathrm{cm}^{3} / \mathrm{g}\right)=\frac{\text { loaf volume }}{\text { loaf weight }}$

\section{Breadcrumb Structure Analysis}

Crumb structure was evaluated quantitatively using image analysis as described by Scheuer, Ferreira, Mationi, Miranda, \& Fransisco (2014) with some

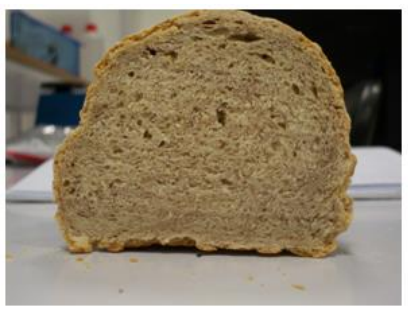

(1)

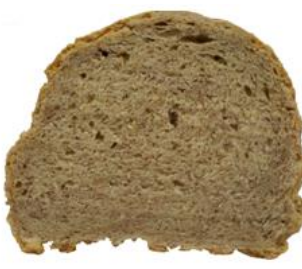

(2)

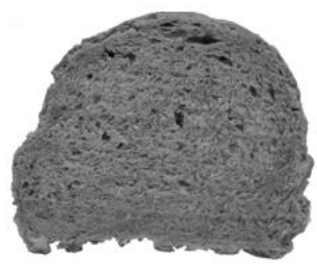

(3)

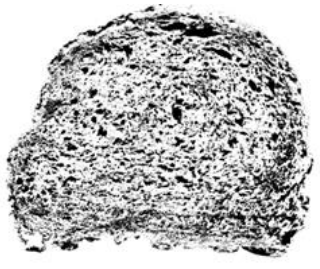

(4)

Figure 1 Preparation of bread cross-section image for breadcrumb structure analysis. From left to right: 1) bread cross-section image captured using camera; 2) isolation of bread cross-section using Adobe Photoshop; 3) conversion of image into 8-bit greyscale image using ImageJ software; 4) application of Otsu's thresholding to the 8-bit greyscale image using ImageJ software

Total number of crumb cells, area of bread cross-section and area of each crumb cell were analyzed using ImageJ software. Crumb cell area distribution was determined by determining the number of cells by classifying them according to Polaki et al. (cited in Scheuer, Ferreira, Mationi, Miranda, \& Fransisco, 2014). Air cells were generally classified as small (area $<4 \mathrm{~mm}^{2}$ ), medium $(4-8$ $\mathrm{mm}^{2}$ ), and large $\left(>8 \mathrm{~mm}^{2}\right)$. Mean crumb cell area and crumb cell density were determined by using the calculation below.

Mean crumb cell area $\left(\mathrm{mm}^{2}\right)=\frac{\text { sum of all crumb cell area }\left(\mathrm{mm}^{2}\right)}{\text { number of detected crumb cells }}$

Crumb cell density $\left(\right.$ cells per $\left.\mathrm{cm}^{2}\right)=\frac{\text { total number of crumb cells }}{\text { area of bread cross-section }\left(\mathrm{cm}^{2}\right)}$

\section{Baking Loss}

Baking loss was determined according to Karaoğlu \& Kotancilar (2006). The dough was weighed prior to baking and after 30 mins of cooling. Baking loss was determined using the calculation below:

Baking loss $(g)=$ dough weight - bread weight

\section{Crumb and Crust Moisture over Storage Time}

This analysis was determined for bread samples which have been stored in closed food containers under room temperature. The analysis was conducted on day 1 (fresh crumb moisture), 3, and 5. On each sampling time, one slice of the bread was obtained. The breadcrumb was separated from the crust and the crumb or crust was minced. As much as $1.008-1.009 \mathrm{~g}$ of the crumb or crust was analyzed using rapid moisture analyzer (MB45 Rapid Moisture Analyzer, OHAUS, New Jersey, U.S.A.) with A90 shut-off setting (constant weight is assumed if no change of sample weight is detected for 90 seconds) at $105^{\circ} \mathrm{C}$.

\section{Statistical Analysis}

Flour proximate compositions were measured in duplicates, while bread physical characteristics were measured in triplicates in three independent measurements. The effect of red kidney bean flour particle size on each bread characteristic parameter was determined by using two-way ANOVA followed by Tukey's honest significant difference (HSD) and two-tailed Dunnett's test. Additionally, two-way ANOVA was also used to determine the statistical significance of interaction effect between red kidney bean flour particle size and concentration XLSTAT (Addinsoft, Paris, France) was used to conduct all statistical analyses, and all analyses were conducted with $95 \%$ confidence level.

\section{RESULTS AND DISCUSSION}

\section{Proximate Composition of Wheat and Red Kidney Bean Flours}

The compositions of the flours were presented in Table 5. High protein white flour used in this study was found to be similar in composition with the composition of enriched bread white flour (United States Department of Agriculture, 2018). Meanwhile, red kidney bean flours in this study were found to be within the range of the result of previous studies, regardless of the particle sizes (Wani, Sogi, Wani, \& Gill, 2013; Siddiq, Ravi, Harte, \& Dolan, 2010) Additionally, they were similar to the typical composition of raw red kidney bean according to ASEAN Food Composition Table (Institute for Nutrition, Mahidol University, 2014). Red kidney bean flour, regardless of the particle size, was found to have significantly higher amount of crude fibre, protein, and ash compared to wheat flour. Red kidney bean, as with other pulses, is rich in dietary fibre, protein, and minerals (Food and Agriculture Organization of the United Nations, 2016).

Particle size reduction of red kidney bean flour was found to change proximate composition of the bean flour. This was similar to the results found by Kerr, Ward, McWaters, \& Resurreccion (2000), in which particle size significantly changed proximate composition of cowpea flour. It was found that red kidney bean flour with smaller particle size has significantly higher carbohydrate, crude fibre, and ash content. Moisture content of red kidney bean flour was found to decrease with smaller particle size. Borsuk, Arntfeld, Lukow, Swallow, \& Malcolmson (2012) found similar results when comparing moisture content of coarse and fine navy and pinto bean flours. Similarly, protein content of red kidney bean flour was found to decrease with smaller particle size. Smaller particle size also yielded red kidney bean flour with fairly similar crude fat, except the one with MF particle size.

Table 5 Proximate composition of wheat and red kidney bean flours

\begin{tabular}{|c|c|c|c|c|c|c|}
\hline \multirow{2}{*}{ Sample } & \multicolumn{6}{|c|}{ Proximate composition $(\%)$} \\
\hline & Moisture & Carbohydrate & Crude fibre & Protein & Crude fat & Ash \\
\hline Wheat flour & $13.50 \pm 0.01^{\mathrm{a}}$ & $72.49 \pm 0.04^{\mathrm{a}}$ & $1.35 \pm 0.02^{\mathrm{a}}$ & $12.33 \pm 0.00^{\mathrm{a}}$ & $1.16 \pm 0.01^{\mathrm{a}}$ & $0.52 \pm 0.00^{\mathrm{a}}$ \\
\hline Red kidney bean flour, MC & $13.22 \pm 0.04^{\mathrm{ab}}$ & $61.30 \pm 0.06^{\mathrm{b}}$ & $2.36 \pm 0.09^{\mathrm{b}}$ & $20.08 \pm 0.08^{b}$ & $1.90 \pm 0.06^{\mathrm{b}}$ & $3.50 \pm 0.00^{\mathrm{b}}$ \\
\hline Red kidney bean flour, MF & $13.36 \pm 0.09^{b}$ & $62.40 \pm 0.17^{\mathrm{c}}$ & $2.67 \pm 0.18^{\mathrm{b}}$ & $19.29 \pm 0.08^{\mathrm{c}}$ & $1.36 \pm 0.01^{\mathrm{c}}$ & $3.59 \pm 0.01^{\mathrm{c}}$ \\
\hline Red kidney bean flour, ST & $11.69 \pm 0.06^{\mathrm{c}}$ & $63.50 \pm 0.12^{\mathrm{d}}$ & $4.79 \pm 0.21^{\mathrm{c}}$ & $19.24 \pm 0.08^{c}$ & $1.93 \pm 0.03^{\mathrm{b}}$ & $3.60 \pm 0.00^{\mathrm{c}}$ \\
\hline
\end{tabular}

Different alphabets in the same column indicate significant difference $(p<0.05)$ between samples. The data are presented as mean \pm standard deviation

\section{Oven Spring and Loaf Specific Volume}

Oven spring is a phenomenon in which dough rises during baking, in which thermal gas expansion is the major factor (Sahi, Little, \& Ananingsih, 2014;
Cauvain, 2007). The result of oven spring yielded no significant difference between samples (Figure 2). This is similar to the result in the study by Mohammed, Ahmed, \& Senge (2014), in which increasing substitution of chickpea flour did not significantly improve oven spring of the bread. 
Meanwhile, red kidney bean flour particle size and concentration did not significantly affect oven spring, whether as separate or combined effect. This is consistent to the result of Borsuk (2011).

Loaf specific volume generally correlates with bread texture, as lower specific volume leads to denser crumb (Cauvain, 2012). No significant difference was found between the samples in terms of loaf specific volume (Figure 3). This is different from previous studies, in which red kidney bean flour addition significantly reduced bread loaf specific volume studies (Mannonmani, Bhol, \& Bosco, 2014; Bhol \& Bosco, 2014). Although not significant, the trend shows that non-control samples varyingly have lower loaf specific volume than control This trend can be also seen in the result of previous similar studies (Mannonmani, Bhol, \& Bosco, 2014; Bhol \& Bosco, 2014). Red kidney bean flour particle size and concentration did not significantly affect loaf specific volume, whether as separate or combined effect. This is also in agreement to the result of Borsuk (2011).

There are several explanations which may relevant to the reduction of loaf specific volume. First, it is possible that physical disruption of gluten network by red kidney bean flour particles occur. Through observation on bread microstructure using scanning electron microscopy, Bhol \& Bosco (2014) found that protein bodies and starch granules of red kidney bean disrupted the gluten network when the bean flour was added to dough. Second, it is also possible that the gluten in the samples were not sufficiently hydrated. As previously discussed, red kidney bean flour was found to have significantly higher crude fibre content compared to wheat flour. Addition of dietary fibre has been found to reduce loaf specific volume due to competition between gluten and fibre for hydration (Cauvain, 2012, Wang, Rossell, \& Barber, 2002; Gómez, Ronda, Blanco, Caballero, \& Apesteguía, 2003). However, deeper analysis should be done to confirm this.

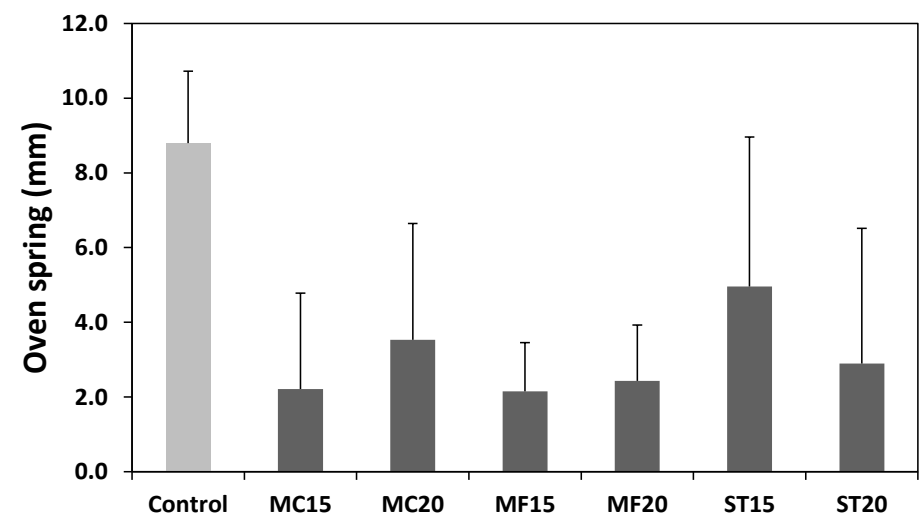

Figure 2 Oven spring of the samples. Data shown are the average of three independent measurements in each sample group. The data are presented as mean \pm standard deviation

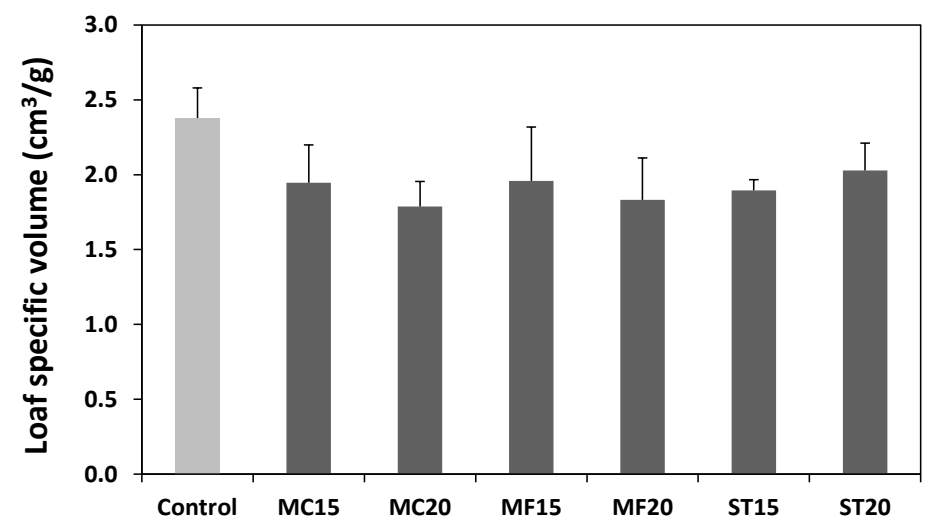

Figure 3 Loaf specific volume of the samples. Data shown are the average of three independent measurements in each sample group. The data are presented as mean \pm standard deviation

\section{Breadcrumb Structure}

Breadcrumb structure is related to bread texture, as small air cells with thin cell walls impart the feeling of soft crumb (Sahi, Little, \& Ananingsih, 2014). In this research, mean crumb cell area and cell density were measured as the indicators of crumb structure quality. Several studies found that addition of pulse flour, such as faba bean or navy bean flour, to bread formulation did not significantly affect breadcrumb structure (Coda, Varis, Verni, Rizzello, \& Katina, 2017). Using crumb cell area size classification based on Polaki et al. (cited in Scheuer, Ferreira, Mationi, Miranda, \& Fransisco, 2014), all of the samples' mean crumb cell areas can be classified as small. Majority of the crumb cells in the samples were also classified as small (data not shown). This indicates good crumb cell size.

In terms of mean crumb cell area, control was found to have no significant difference to the other samples (Figure 4). However, when comparing noncontrol samples, red kidney bean flour particle size was found to significantly affect mean crumb cell area, with the largest particle size (MC) having the largest mean crumb cell area.

Meanwhile, in terms of crumb cell density, control generally did not have significant difference to other samples except MF20 and ST20 (Figure 5). When comparing non-control samples, red kidney bean flour particle size was found to significantly affect crumb cell density, with the largest particle size (MC) having the lowest crumb cell density.

It is clear that red kidney bean flour particle size reduction improved bread mean crumb cell area and crumb cell density. This is similar to the result of Borsuk (2011), in which lentil flour particle size reduction significantly improved bread crumb cell elongation. This may be because red kidney bean flour particle size reduction reduced the detrimental influence of insoluble dietary fibre in the bread, therefore improving the bread microstructure. Martínez, Díaz, \& Goméz (2014) found that insoluble dietary fibre caused more open irregular dough microstructure in gluten-free bread, and reducing particle size of the fibre reduced this detrimental effect. This may also be caused by reduced physical disruption of gluten network by red kidney bean flour particles, which allows improved crumb cell generation (Mohammed, Ahmed, \& Senge, 2014).

When comparing non-control samples, red kidney bean flour concentration did not significantly affect mean crumb cell area and crumb cell density (Figure $4 \&$ 5). Meanwhile, interaction between particle size and concentration significantly affect those parameters only on several sample comparisons, mostly between samples with different particle sizes. Therefore, it is expected that the significance in the interaction effect is influenced by red kidney bean flour particle size, not concentration. This further supports the important role of red kidney bean particle size on crumb structure.

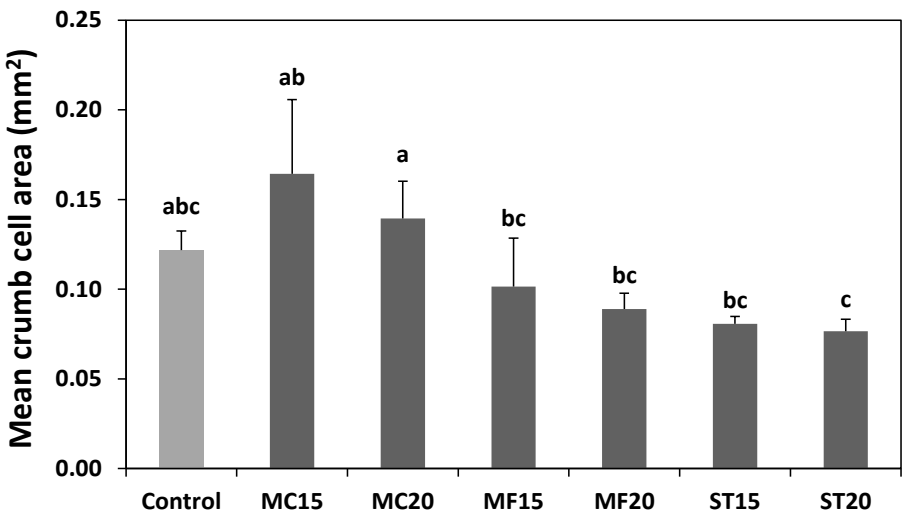

Figure 4 Mean crumb cell area of the samples. Data shown are the average of three independent measurements in each sample group. The data are presented as mean \pm standard deviation. Significant difference $(p<0.05)$ is indicated when alphabetic markers between samples are different

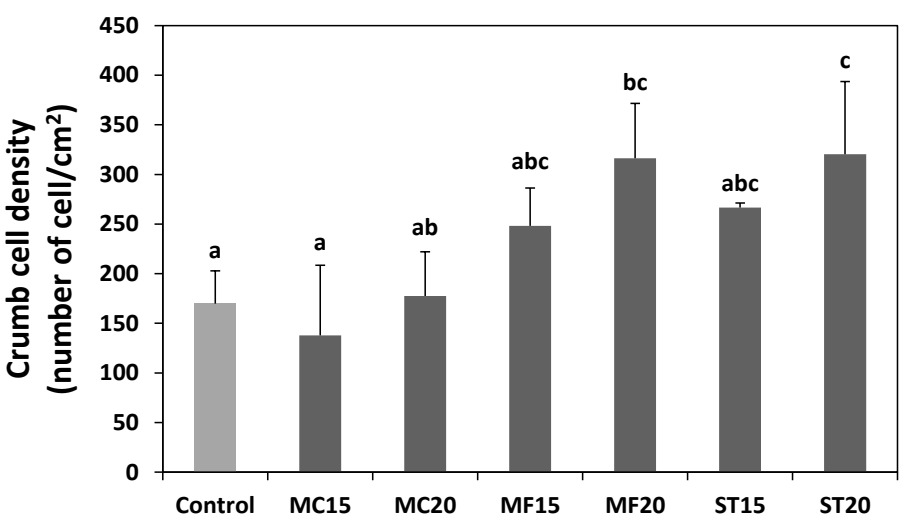

Figure 5 Crumb cell density of the samples. Data shown are the average of three independent measurements in each sample group. The data are presented as mean \pm standard deviation. Significant difference $(p<0.05)$ is indicated when alphabetic markers between samples are different

\section{Baking Loss}

Baking loss is the loss of weight in bread after baking, which is usually attributed to moisture loss (Cauvain \& Young, 2008). Therefore, if baking loss is high, 
moisture loss is also high, and this may impair the perception of freshness in bread. It was expected that addition of red kidney bean flour, which has higher crude fibre content than wheat flour, would reduce baking loss of the samples due to the capability of dietary fibre to retain moisture (Cauvain \& Young, 2008) However, no significant difference was found when comparing baking loss of the samples (Figure 6).

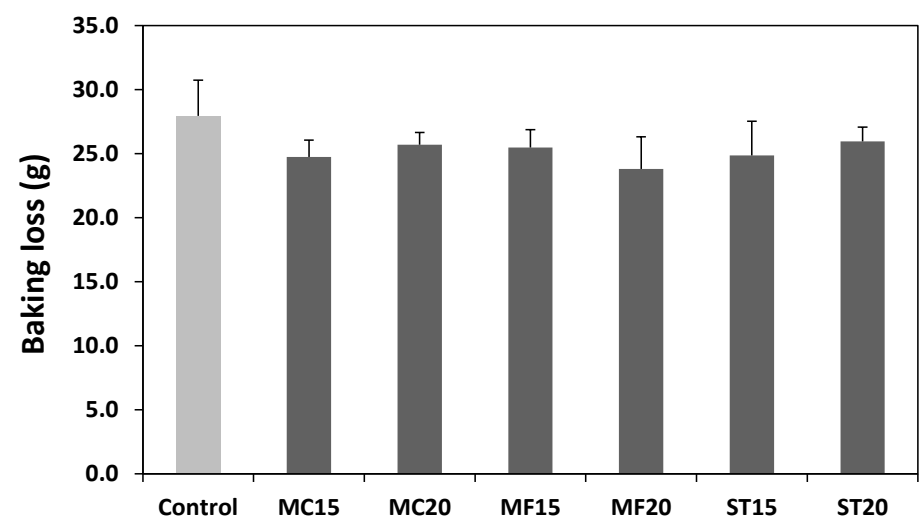

Figure 6 Baking loss of the samples. Data shown are the average of three independent measurements in each sample group. The data are presented as mean \pm standard deviation

\section{Crumb and Crust Moisture over Storage Time}

Crumb and crust moisture is an indicator for staling, a phenomenon in which bread becomes hard due to moisture loss (Cauvain, 2004). In this research, bread moisture analysis was separated into crumb and crust moisture analysis over storage time. This was done to see whether there is moisture migration from crumb to crust. From Figure 7 and 8, moisture migration from crumb to crust occurred. This is consistent to the result of Purhagen, Sjöö, \& Eliasson (2012). On day 1 , crumb and crust moisture of the samples was similar and no significant difference between samples was found (Figure 7 and Figure 8). This was consistent to the result of baking loss, which also showed the same trend. However, over storage time, greater variations between samples were found. Despite this, no significant difference was found between samples. This is more likely due to batch-to-batch variations and uneven moisture distribution on the bread, as also shown by Purhagen, Sjöö, \& Eliasson (2012). The lack of significant difference of crumb and crust moisture between non-control samples may also be possible due to the lack of significant difference in water absorption capacity of dietary fibre with different particle size (Ktenioudaki \& Gallagher, 2012).

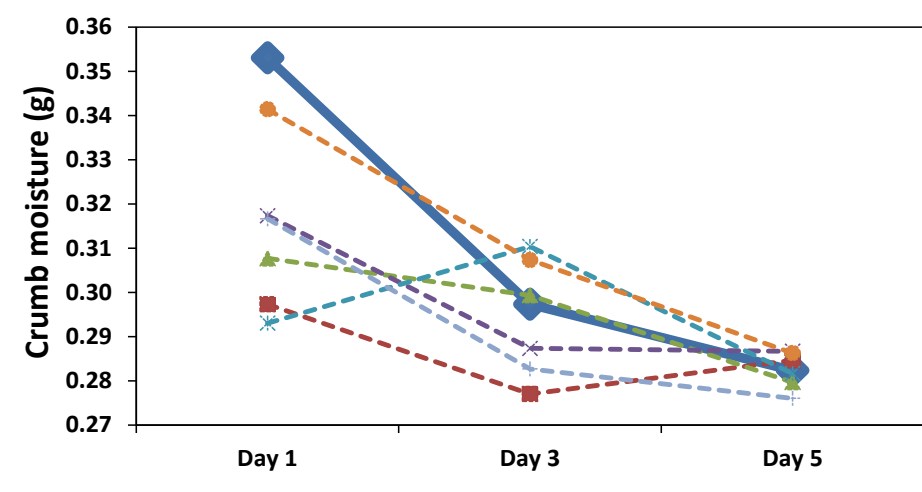

Figure 7 Samples' crumb moisture over storage time. Data shown are the average of three independent measurement of each sample group in each sampling time. Data are presented as line chart representing mean crumb moisture per sample group

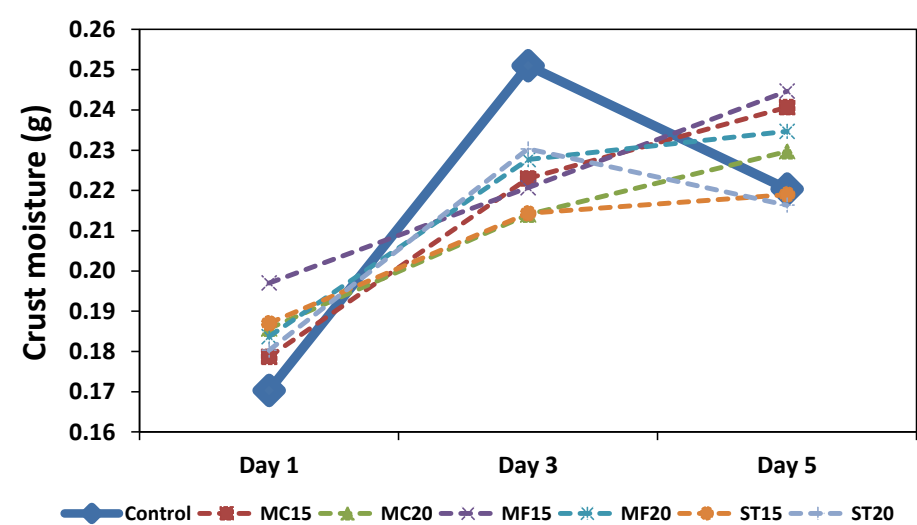

Figure 8 Samples' crust moisture over storage time. Data shown are the average of three independent measurement of each sample group in each sampling time. Data are presented as line chart representing mean crumb moisture per sample group

When control crumb moisture on day 1,3 , and 5 were compared, significant difference was found; crumb moisture on day 5 was significantly lower than moisture on previous sampling times (Figure 7). This trend did not occur on noncontrol samples. This implied that control had a more significant staling compared to non-control samples. This may be caused by the enhanced water retention capability of the non-control samples due to higher amount of fibre from red kidney bean flour. Dietary fibre has been found to increase and retain moisture content of bread (Cauvain \& Young, 2008; Wang, Rossell, \& Barber, 2002). However, a deeper analysis is needed to confirm this.

When control crust moisture on day 1,3 , and 5 were compared, significant difference was not found (Figure 8). This trend was the same for all non-control samples except MC15, MF15, and MF20. On MC15, crust moisture on day 3 and 5 were significantly higher than day 1 (fresh crust moisture). This indicated that significant crust softening occurred on MC15 on the third day. On MF15 and MF20, crust moisture on day 5 was significantly higher than day 1 and 3. This indicated that significant crust softening occurred on MF15 and MF20 on the fifth day. However, this was not consistent with the crumb moisture data, in which crumb moisture of MC15, MF15, and MF20 on day 1 and 5 were not significantly different. The random effect of crust hygroscopicity in the samples may explain this; it is possible that crust of the samples did not only absorb moisture from the crumb, but also from air.

\section{CONCLUSION}

Addition of red kidney bean flour was not found to significantly improve white bread physical characteristics. Red kidney bean flour concentration was not found to significantly influence white bread physical characteristics. Red kidney bean flour particle size reduction had positive significant effect on mean crumb cell area and crumb cell density, but had no significant effect on other bread physical characteristics.

Based on the effect of red kidney bean flour on white bread physical characteristics, red kidney bean flour may be more suitable to be applied for unleavened bread, such as flatbread and tortilla. Such application enables application of red kidney bean flour in higher concentration with more tolerance to the bread physical characteristics. Therefore, application of red kidney bean flour in unleavened bread, in addition to optimization of such application, can be explored in future studies.

For future studies which explore the application on red kidney bean flour on bread, several aspects of this study can be improved. Future studies can compare between open and pan bread loaves. Higher red kidney bean flour concentrations (larger gap between different concentrations) with different particle sizes can be tested to observe the effect of concentration and concentration-particle size interaction better. The study can also benefit from exploring the application of different fractions of the red kidney bean (e.g. dehulled bean, whole bean, and hull) with different particle sizes and concentrations on bread.

\section{REFERENCES}

American Association of Cereal Chemists. (2000). Approved methods, Method 10-10B. Optimized straight dough bread-making method.

Association of Official Analytical Chemists. (1990). Official methods of analysis (15th ed.). Washington, DC: Association of Official Analytical Chemists.

Atkinson, F. S., Foster-Powell, K., \& Brand-Miller, J. C. (2008). International tables of glycemic index and glycemic load values: 2008. Diabetes Care, 31(12), 2281-2283. https://doi.org/10.2337/dc08-1239

Barbosa-Canovas, G. V., Ortega-Rivas, E., Juliano, P., \& Yan, H. (2006). Food powders: physical properties, processing, and functionality. Springer Science \& Business Media. 
Bhol, S., \& Bosco, S. J. D. (2014). Influence of malted finger millet and red kidney bean flour on quality characteristics of developed bread. LWT-Food Science and Technology, 55(1), 294-300. https://doi.org/10.1016/j.lwt.2013.08.012

Borsuk, Y. (2011). Incorporation of pulse flours with coarse and fine particle size milled from green lentils (Lens culinars), yellow peas (Pisum sativum L.), navy beans (Phaselous vulgaris L.), and pinto beans (Phaselous vulgari L.) into baked products (Thesis). Taken from https://mspace.lib.umanitoba.ca/bitstream/handle/1993/4803/borsuk_yulia.pdf?se quence $=1$

Borsuk, Y., Arntfield, S., Lukow, O. M., Swallow, K., \& Malcolmson, L. (2012). Incorporation of pulse flours of different particle size in relation to pita bread quality. Journal of the Science of Food and Agriculture, 92(10), 2055-2061. https://doi.org/10.1002/jsfa.5581

Campbell, G. M., Webb, C., Owens, G. W., \& Scanlon, M. G. (2012). Milling and flour quality. In Breadmaking (pp. 188-215). Woodhead Publishing. https://doi.org/10.1533/9780857095695.1.188

Cauvain, S. P. (2004). Improving the texture of bread. In Texture in Food (pp. 432-450). Woodhead Publishing.

Cauvain, S. P. (2007). Technology of Breadmaking. UK: Springer. https://doi.org/10.1007/978-3-319-14687-4

Cauvain, S., \& Young, L. (2000). Water and its roles in baked products. In Bakery Food Manufacture and Quality: Water Control and Effects (pp. 11-195). Oxford: Blackwell Science. https://doi.org/10.1002/9781444301083.ch1

Coda, R., Varis, J., Verni, M., Rizzello, C. G., \& Katina, K. (2017). Improvement of the protein quality of wheat bread through faba bean sourdough addition. LWT Food Science and Technology, 82, 296-302. https://doi.org/10.1016/j.lwt.2017.04.062

Duodu, K. G., \& Taylor, J. R. N. (2012). The quality of breads made with nonwheat flours. In Breadmaking (pp. 754-782). Woodhead Publishing. https://doi.org/10.1533/9780857095695.4.754

EU-Indonesia Business Network. (2016). EIBN Sector Report: Bakery Ingredient. $\quad$ Retrieved from http://indonesien.ahk.de/fileadmin/ahk_indonesien/Publications/EIBN/EIBNSec Rep2016_Bakery_Ingredients_FULL-40350.pdf.

Food and Agriculture Organization of the United Nations. (2016). Pulses: Nutritious Seeds for a Sustainable Future. Rome: Food and Agriculture Organization of the United Nations.

Gómez, M., Ronda, F., Blanco, C. A., Caballero, P. A., \& Apesteguía, A. (2003) Effect of dietary fibre on dough rheology and bread quality. European Food Research and Technology, 216(1), 51-56. https://doi.org/10.1007/s00217-0020632-9

Health Research and Development Agency, Ministry of Health of Indonesia. (2013). Riset Kesehatan Dasar 2013 [in Bahasa]. Jakarta: Health Research and Development Agency, Ministry of Health of Indonesia.

Institute of Nutrition, Mahidol University. (2014). ASEAN Food Composition Database, Electronic version 1, February 2014, Thailand http://www.inmu.mahidol.ac.th/aseanfoods/composition_data.html.

Karaoğlu, M. M., \& Kotancilar, H. G. (2006). Effect of partial baking, storage and rebaking process on the quality of white pan bread. International Journal of Food Science \& Technology, 41(s2), 108-114. https://doi.org/10.1111/j.13652621.2006.01432.x

Kerr, W. L., Ward, C. D. W., Mcwatters, K. H., \& Resurreccion, A. V. A. (2000) Effect of milling and particle size on functionality and physicochemical properties of cowpea flour. Cereal Chemistry, 77(2), 213-219. https://doi.org/10.1094/CCHEM.2000.77.2.213

Ktenioudaki, A., \& Gallagher, E. 2012. Recent advances in the development of high-fibre baked products. Trends in Food Science \& Technology, 28(1), 4-14. https://doi.org/10.1016/j.tifs.2012.06.004

Manonmani, D., Bhol, S., \& Bosco, S. J. D. (2014). Effect of red kidney bean (Phaseolus vulgaris L.) flour on bread quality. Open Access Library Journal, 1 , 1-6. https://doi.org/10.4236/oalib.1100366

Mohammed, I., Ahmed, A. R., \& Senge, B. (2014). Effects of chickpea flour on wheat pasting properties and bread making quality. Journal of Food Science and Technology, 51(9), 1902-1910. https://doi.org/10.1007/s13197-012-0733-9

Pekerti, S. \& Slette, J. (2010). USDA GAIN Report: Bakery Products Ingredient - Jakarta, Indonesia. $\quad$ Retrieved from https://gain.fas.usda.gov/Recent\%20GAIN\%20Publications/Grain\%20and\%20Fe ed\%20Annual_Jakarta_Indonesia_3-30-2017.pdf.

Purhagen, J. K., Sjöö, M. E., \& Eliasson, A. C. (2012). Fibre-rich additives- the effect on staling and their function in free-standing and pan-baked bread. Journal of the Science of Food and Agriculture, 92(6), 1201-1213. https://doi.org/10.1002/jsfa.4684

Rizzello, C. G., Calasso, M., Campanella, D., De Angelis, M., \& Gobbetti, M. (2014). Use of sourdough fermentation and mixture of wheat, chickpea, lentil and bean flours for enhancing the nutritional, texture and sensory characteristics of white bread. International Journal of Food Microbiology, 180, 78-87. https://doi.org/10.1016/j.ijfoodmicro.2014.04.005
Sahi, S. S., Little, K., \& Ananingsih, V. K. (2014). Quality control. In Bakery Products Science and Technology (pp. 489-510). Wiley-Blackwell. https://doi.org/10.1002/9781118792001.ch28

Scheuer, P. M., Ferreira, J. A. S., Mattioni, B., Miranda, M. Z. D., \& Francisco, A. D. (2015). Optimization of image analysis techniques for quality assessment of whole-wheat breads made with fat replacer. Food Science and Technology (Campinas), 35(1), 133-142. https://doi.org/10.1590/1678-457x.6560

Shittu, T. A., Dixon, A., Awonorin, S. O., Sanni, L. O., \& Maziya-Dixon, B. (2008). Bread from composite cassava-wheat flour. II: Effect of cassava genotype and nitrogen fertilizer on bread quality. Food Research International, 41(6), 569-578. https://doi.org/10.1016/j.foodres.2008.03.008

Sivam, A. S., Sun-Waterhouse, D., Quek, S. Y., \& Perera, C. O. (2010) Properties of bread dough with added fiber polysaccharides and phenolic antioxidants: a review. Journal of Food Science, 75(8), R163-R174. https://doi.org/10.1111/j.1750-3841.2010.01815.x

Suwanto, W. \& Yapply, J. F. (2017). BCA Sekuritas Equity Research: Nippon Indosari Corpindo. Retrieved from http://bcasekuritas.co.id.

Ugwuona, F. U., \& Suwaba, S. (2015). Effects of defatted jack bean flour and jack bean protein concentrate on physicochemical and sensory properties of bread. Nigerian Food Journal, 31(2), 25-32. https://doi.org/10.1016/s0189 7241(15)30073-4

United States Department of Agriculture. (2018). Full Report (All Nutrients) 20083, Wheat flour, white, bread, enriched. Taken from: https://ndb.nal.usda.gov/ndb/foods/show/20083.

Viswanathan, K., \& Ho, P. (2014). Fortification of white flat bread with sprouted red kidney bean (Phaseolus vulgaris). Acta Scientiarum Polonorum Technologia Alimentaria, 13(1), 27-34. https://doi.org/10.17306/j.afs.2014.1.2

World Health Organization \& Food and Agriculture Organization of the United Nations. (2007). Codex Alimentarius: Cereals, Pulses, Legumes and Vegetable Proteins ( $1^{\text {st }}$ ed.). Rome, Italy: Food and Agriculture Organization of the United Nations. 